\title{
Microcredit and health
}

\author{
Paul Malik MD FRCPC
}

$\mathrm{P}_{\mathrm{h}}^{\mathrm{h}}$ hysics describes four known forces - strong nuclear force, electromagnetism, weak nuclear force and gravitation. The modern holy grail of physics is to link these forces in a single 'field' described through the language of mathematics, which is known as the unified field theory or universal theory. As a matter of analogy, I offer four forces that describe humanity - nature (or genetics), nurture (upbringing, or collective sum of experiences), health (physical stability used to improve individual station) and economics (insofar as misdistribution of wealth creates misdistribution of opportunity). The interplay of these four forces may be used to understand everything from acts of kindness to genocide. Some degree of unification is readily apparent, yet some linkages may not be readily apparent. The union of health and economics is an important one.

In general, the rich have better quality and quantity of life than the poor. Is this because of improved living conditions, better education and access to health care for the rich, or is it because those who are healthy are able to accumulate wealth? The question lies at the heart of how best to deliver health care to the poor. Traditional delivery in the form of medicine and surgery is end-stage. To truly deliver health care to the poor is to deliver wealth-generating power. As arbiters of health, physicians have the power to influence this social imperative.

Poverty is the greatest and most difficult problem faced by this and every other generation thus far. It is a problem that has the power to influence everyone, because poverty or extreme economic disproportion is frequently the root cause of many cases of social unrest. Racial or religious disgruntlement only lights the fuse. Controlling the problem of poverty will require a myriad of complementary solutions. One such solution can be found in the work of 2006 Nobel Laureate, Muhammad Yunus, on microcredit. The idea of microcredit is to give small, graduated loans to individuals or groups who cannot offer any collateral and do not have a credit history. Traditional banks have shied away from these groups because they are deemed to be at excessive risk of default on the loan, and also because of the excessive costs in monitoring and enforcing the transactions. As such, the poor fall victim to loan sharks and become enmeshed in a debt trap. Microcredit, while delivered with a socially beneficial conscience, is not charity, and allows the poor to become self-sustaining and develop a credit history for entry into the middle class. While Yunus did not invent the idea of microcredit, he did demonstrate its successes and develop its practical abilities, and his receipt of the Nobel Peace Prize has certainly popularized it.
In the 1970s, Yunus found a number of people in one particular village in Bangladesh indebted to a local loan shark for a total of US\$27. He gave these individuals the small sum and was moved by the extraordinary effect it had. He also recognized the economic value of the poor. In his own words, "giving the poor access to credit allows them to immediately put into practice the skills they already know - to weave, husk rice paddy, raise cows, peddle a rickshaw. And the cash they earn is then a tool, a key that unlocks a host of other abilities and allows them to explore their own potential". At first glance, it would seem that microcredit is ideally designed for those just under the poverty line or those with ability but no capital to carry it out. Not so. Through Yunus's painstaking work with beggars, he was able to reach the poorest of the poor by employing them as personal shoppers or door-to-door salesmen!

Another added benefit to microcredit is that lending is done preferentially to women. In developing nations, where men typically control money, this policy promotes sex equality by providing women with economic power and the ability to engage in the development of the community. The policy, however, is borne of practical reasons rather than social justice. Experience has shown that women, in general, spend their money on improving their family and children, and are more likely to spend it on improving their business, while men spend more on themselves.

However, microfinance is not a panacea for poverty itself and has many detractors. Critics argue that it is a kinder, gentler form of loan sharking. The high interest rates necessary to maintain its economic viability and pressure to make the payments has forced borrowers to sell household goods and land, and forego food; it has even resulted in suicides. Ensuring that the borrowers are truly poor (ie, without access to traditional financial services) and that the loan is truly used to generate income are other major problems.

It is clear that microfinance cannot be used in isolation, but must be instituted with other more traditional poverty alleviation initiatives, such as provision of food aid, basic health services and security. Its principles have proven to be so powerful in practice that it is also being applied to poverty in developed nations. If we return to the problem of social unrest lying on the powder keg of poverty, we see that there is another ingredient in the mix - idleness. Poverty combined with idleness breeds contempt. Microfinance, by providing gainful self-employment, is one attempt to address both of these factors. It is noteworthy that Yunus, a trained economist, was awarded the Nobel Prize not for economics, but for peace.

\section{Selected sites}

1. Wikipedia
<en.wikipedia.org/wiki/Microcredit>
2. CSA Illumina - Discovery Guide
<www.csa.com/discoveryguides/microfinance/review.php>
3. Grameen
<www.grameen-info.org>

4. The New York Times <www.nytimes.com/slideshow/2008/04/01/nyregion/0401GRAMEEN_index.html>

5. YouTube

$<$ www.youtube.com/watch?v=E615UKQWAWo\&feature=related $>$

Staff Interventional Cardiologist, Queen's University, Kingston, Ontario

For comments or to suggest a Web site for discussion in a future column, write to pgmalik@hotmail.com 